\title{
Cross-floating calibration study. Trim masses: on the standard balance or on the balance under calibration
}

\author{
Francisco Flores, Jorge Torres \\ Centro Nacional de Metrologia km 4.5 Carretera a los Cues, Mpio. El Marques, C:P. 76246 Queretaro, Mexico
}

ABSTRACT

The pressure balances are used as reference standards to calibrate secondary manometers and other balances. There are different types and models of pressure balances that cover measuring ranges from $3 \mathrm{kPa}$ to $1 \mathrm{GPa}$. The pressure balances are designed to measure relative, absolute or differential pressure and some balances can measure all types of pressure. This paper presents the results of a study of high accuracy pressure balances cross-floating calibration comparing trim masses on the standard balance or on the balance under calibration.

\section{Section: TECHNICAL NOTE}

Keywords: pressure balances; cross-floating calibration; trim masses

Citation: Francisco Flores, Jorge Torres, Cross-floating calibration study. Trim masses: on the standard balance or on the balance under calibration, Acta IMEKO, vol. 7, no. 1, article 17, March 2018, identifier: IMEKO-ACTA-07 (2018)-01-17

Section Editor: Paul Regtien, Measurement Science Consultancy, The Netherlands

Received July 27, 2017; In final form November 22, 2017; Published March 2018

Copyright: @ $\odot 2018$ IMEKO. This is an open-access article distributed under the terms of the Creative Commons Attribution 3.0 License, which permits unrestricted use, distribution, and reproduction in any medium, provided the original author and source are credited

Corresponding author: Francisco Flores, e-mail: fflores@cenam.mx

\section{INTRODUCTION}

The pressure balances are used as reference standards to calibrate secondary manometers and other balances. There are different types of pressure balances covering ranges from $3 \mathrm{kPa}$ to $1 \mathrm{GPa}$. The pressure balances measure relative, absolute or differential pressure and some measure all types of pressure. This paper is a part of a project within Mexico to aid secondary calibration laboratories to better use their high accuracy pressure balances for calibration and internal traceability. The calibration of pressure balances or dead weight balances is of high importance in secondary laboratories, as well as in industry. This type of calibrations is performed by the crossfloating method. The method is for two pressure balances, connected together using a manometric fluid (i.e. gas or liquid) which transmits the pressure between them; the equilibrium must be achieved by adding or removing trim masses (small masses), either in the standard balance or in the balance under calibration. The piston-cylinder of each balance must be located at its floating level.

In Mexico, more than 12 secondary laboratories have high accuracy pressure balances as calibration standards. This paper presents the results of a study of high accuracy pressure balances cross-floating calibration comparing the use of the trim masses on the standard balance or on the balance under calibration [1]-[3].

\section{STUDY}

Two piston-cylinder calibrations (DH Instruments, 5300 model, 8666 serial number, $20 \mathrm{MPa}$ maximum range, CENAMs property) were made (Table 1). The reference standard used was a DH Instruments, 5300 model, 5716 serial number pistoncylinder, $100 \mathrm{MPa}$ maximum range. On the first calibration, the trim masses were added on the pressure balance under

Table 1. Standards used.

\begin{tabular}{lcc}
\hline Description & $\begin{array}{l}\text { Balance Under } \\
\text { Calibration }\end{array}$ & Standard Balance \\
\hline Manufacturer & DH Instruments & DH Instruments \\
Model & 5300 & 5300 \\
Serial number & 8666 & 5716 \\
Range & $0.04 \mathrm{MPa}$ to $20 \mathrm{MPa}$ & $0.2 \mathrm{MPa}$ to $100 \mathrm{MPa}$
\end{tabular}


Calibration (Table 2). In the second calibration, the trim masses were added on the standard pressure balance (Table 3).

\section{RESULTS}

To evaluate the results obtained from the two calibrations the criteria used was the normalized error equation method.

$E_{\mathrm{n}}=\frac{x_{\mathrm{cal}}-x_{\mathrm{ref}}}{\sqrt{U_{\mathrm{cal}}^{2}-U_{\mathrm{ref}}^{2}}}$

where:

$E_{\mathrm{n}} \quad$ is the normalized error;

$x_{\text {cal }} \quad$ is the area obtained by one method of calibration;

$x_{\text {ref }}$ is the area obtained by the other method of calibration;

$U_{\text {cal }} \quad$ is the expanded uncertainty estimated for one method of calibration, $(k=2)$;

$U_{\text {ref }} \quad$ is the expanded uncertainty estimated for the other method of calibration, $(k=2)$.

From the normalized error equation model, if:

$\left|E_{\mathrm{n}}\right| \leq 1$ the results are compatible,

$\left|E_{\mathrm{n}}\right|>1$ the results are not compatible.

By means of the results included in Tables 2 and 3, we can obtain the effective area and its uncertainty, for each type of calibrations as shown in Tables 4 and 5 .

Figure 1 shows the results obtained in Tables 4 and 5 for the effective area $A_{\text {effe }}$ and its uncertainty.

Normalized error equation method results can be calculated by means of the data in Tables 4 and 5 , as presented in Table 6 .

Figure 2 graphs the results included in Table 6.

Additionally to the calibrations made with the Mexican National Standard shown before (Figures 1 and 2), using the results from the original calibration made by the manufacturer for $A_{0}$, we can compare the results from both calibrations for $A_{0}$, as shown in Table 7 , where $A_{0}$ is the effective area at zero pressure.

Table 2. Adding trim masses to the balance under calibration.

\begin{tabular}{lcc}
\hline $\begin{array}{c}\text { Nominal } \\
\text { pressure } \\
\text { / MPa }\end{array}$ & $\begin{array}{c}\text { Masses, Standard } \\
\text { balance / kg }\end{array}$ & $\begin{array}{c}\text { Masses, Balance } \\
\text { under calibration / kg }\end{array}$ \\
\hline 2.0 & 2.0 & 10.004050 \\
4.0 & 4.0 & 20.004570 \\
6.0 & 6.0 & 30.004910 \\
10.0 & 10.0 & 50.005100 \\
14.0 & 14.0 & 70.005060 \\
18.0 & 18.0 & 90.006250 \\
20.0 & 20.0 & 100.007120
\end{tabular}

Table 3. Adding trim masses to the standard balance.

\begin{tabular}{lcc}
\hline $\begin{array}{c}\text { Nominal } \\
\text { pressure } \\
\text { / MPa }\end{array}$ & $\begin{array}{c}\text { Masses, Standard } \\
\text { balance / kg }\end{array}$ & $\begin{array}{c}\text { Masses, Balance } \\
\text { under calibration / kg }\end{array}$ \\
\hline 2.0 & 1.998900 & 10.0 \\
4.0 & 3.998870 & 20.0 \\
6.0 & 5.998940 & 30.0 \\
10.0 & 9.998930 & 50.0 \\
14.0 & 13.998770 & 70.0 \\
18.0 & 17.998750 & 90.0 \\
20.0 & 19.998730 & 100.0
\end{tabular}

Table 4. Results adding trim masses to the balance under calibration.

\begin{tabular}{ccccc}
\hline $\begin{array}{c}\text { Pressure } \\
\text { / kPa }\end{array}$ & $\begin{array}{c}\boldsymbol{A}_{\text {effe }}\left(\mathbf{2 0}{ }^{\circ} \mathbf{C}\right) \\
/ \mathbf{~ m}^{2}\end{array}$ & $\begin{array}{c}\text { Uncertainty } \\
/ \mathbf{~ m}^{2}\end{array}$ & $\begin{array}{c}\text { Relative } \\
\text { uncertainty } \\
/ \boldsymbol{A}_{\text {effe }}\end{array}$ & $\begin{array}{c}\text { Pressure } \\
\text { due to the } \\
\text { trim masses } \\
/ \mathbf{~ k P a}\end{array}$ \\
\hline 1995.560 & $4.90272 \mathrm{E}-05$ & $\pm 1.8 \mathrm{E}-09$ & $\pm 37 \mathrm{E}-06$ & 0.835 \\
3990.331 & $4.90282 \mathrm{E}-05$ & $\pm 1.7 \mathrm{E}-09$ & $\pm 35 \mathrm{E}-06$ & 1.343 \\
5985.121 & $4.90281 \mathrm{E}-05$ & $\pm 1.7 \mathrm{E}-09$ & $\pm 35 \mathrm{E}-06$ & 1.700 \\
9974.638 & $4.90278 \mathrm{E}-05$ & $\pm 1.7 \mathrm{E}-09$ & $\pm 35 \mathrm{E}-06$ & 0.880 \\
13964.110 & $4.90279 \mathrm{E}-05$ & $\pm 1.7 \mathrm{E}-09$ & $\pm 35 \mathrm{E}-06$ & 1.131 \\
17953.648 & $4.90282 \mathrm{E}-05$ & $\pm 1.7 \mathrm{E}-09$ & $\pm 35 \mathrm{E}-06$ & 1.134 \\
19948.393 & $4.90285 \mathrm{E}-05$ & $\pm 1.7 \mathrm{E}-09$ & $\pm 35 \mathrm{E}-06$ & 1.413
\end{tabular}

Table 5. Results adding trim masses to the standard balance.

\begin{tabular}{ccccc}
\hline $\begin{array}{c}\text { Pressure } \\
/ \mathbf{~ k P a}\end{array}$ & $\begin{array}{c}\boldsymbol{A}_{\text {effe }}\left(\mathbf{2 0}{ }^{\circ} \mathrm{C}\right) \\
/ \mathbf{~ m}^{2}\end{array}$ & $\begin{array}{c}\text { Uncertainty } \\
/ \mathbf{~ m}^{2}\end{array}$ & $\begin{array}{c}\text { Relative } \\
\text { uncertainty } \\
/ \boldsymbol{A}_{\text {effe }}\end{array}$ & $\begin{array}{c}\text { Pressure } \\
\text { due to the } \\
\text { trim masses } \\
/ \mathbf{~ k P a}\end{array}$ \\
\hline 1994.499 & $4.90335 \mathrm{E}-05$ & $\pm 1.8 \mathrm{E}-09$ & $\pm 37 \mathrm{E}-06$ & 1.473 \\
3989.208 & $4.90308 \mathrm{E}-05$ & $\pm 1.7 \mathrm{E}-09$ & $\pm 35 \mathrm{E}-06$ & 1.658 \\
5984.078 & $4.90286 \mathrm{E}-05$ & $\pm 1.7 \mathrm{E}-09$ & $\pm 35 \mathrm{E}-06$ & 1.733 \\
9973.585 & $4.90280 \mathrm{E}-05$ & $\pm 1.7 \mathrm{E}-09$ & $\pm 35 \mathrm{E}-06$ & 1.718 \\
13962.929 & $4.90283 \mathrm{E}-05$ & $\pm 1.7 \mathrm{E}-09$ & $\pm 35 \mathrm{E}-06$ & 1.575 \\
17952.378 & $4.90282 \mathrm{E}-05$ & $\pm 1.7 \mathrm{E}-09$ & $\pm 35 \mathrm{E}-06$ & 1.548 \\
19947.078 & $4.90282 \mathrm{E}-05$ & $\pm 1.7 \mathrm{E}-09$ & $\pm 35 \mathrm{E}-06$ & 1.523
\end{tabular}

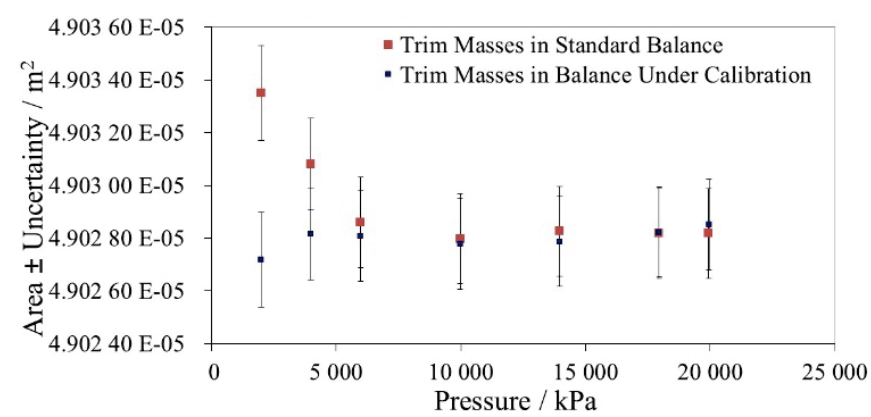

Figure 1. Results of effective area and its uncertainty for both calibrations made.

Table 6. Results adding trim masses to the standard balance.

\begin{tabular}{cccc}
\hline $\begin{array}{c}\text { Pressure } \\
\text { / kPa }\end{array}$ & $\begin{array}{c}\text { Trim masses on the } \\
\text { standard balance } \\
\boldsymbol{A}_{\text {effe }}\left(\mathbf{2 0}^{\circ} \mathbf{C}\right) \\
/ \mathbf{~ m}^{2}\end{array}$ & $\begin{array}{l}\text { Trim masses on } \\
\text { the balance under } \\
\text { calibration } \\
\boldsymbol{A}_{\text {effe }}\left(\mathbf{2 0} \mathbf{~}^{\circ} \mathbf{C}\right) \mathbf{~ m}^{2}\end{array}$ & $\boldsymbol{E}_{\mathbf{n}}$ \\
\hline 1994.499 & $4.90335 \mathrm{E}-05$ & $4.90272 \mathrm{E}-05$ & 2.5 \\
3989.208 & $4.90308 \mathrm{E}-05$ & $4.90282 \mathrm{E}-05$ & 1.1 \\
5984.078 & $4.90286 \mathrm{E}-05$ & $4.90281 \mathrm{E}-05$ & 0.22 \\
9973.585 & $4.90280 \mathrm{E}-05$ & $4.90278 \mathrm{E}-05$ & 0.08 \\
13962.929 & $4.90283 \mathrm{E}-05$ & $4.90279 \mathrm{E}-05$ & 0.16 \\
17952.378 & $4.90282 \mathrm{E}-05$ & $4.90282 \mathrm{E}-05$ & 0.02 \\
19947.078 & $4.90282 \mathrm{E}-05$ & $4.90285 \mathrm{E}-05$ & 0.14
\end{tabular}

\section{DISCUSSION}

During the calibrations, all considerations for effective area pressure balance procedure were taken into account. From the two calibrations made, there are only one point bigger than one, $E_{\mathrm{n}}$, with not compatible results. The form to realize the 


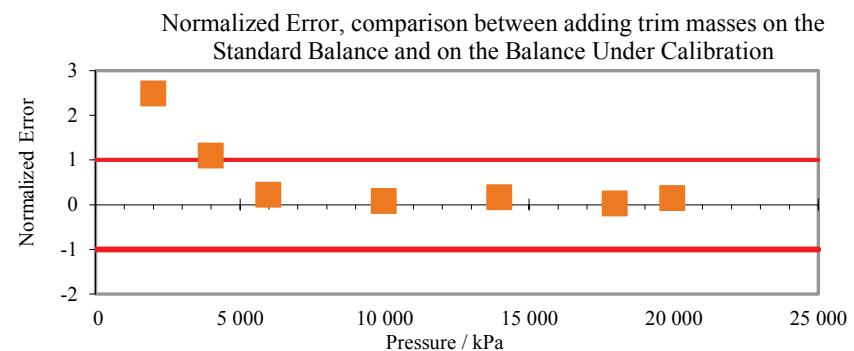

Figure 2. Normalized error equation results for the two calibrations.

Table 7. Normalized error equation results of the two calibrations using the manufacturer's first calibration information as reference.

\begin{tabular}{lcccc}
\hline \multicolumn{1}{c}{ Description } & $\begin{array}{c}\boldsymbol{A}_{\mathbf{0}}\left(\mathbf{2 0}{ }^{\circ} \mathrm{C}\right) \\
/ \mathbf{~ m}^{\mathbf{2}}\end{array}$ & $\begin{array}{c}\text { Uncertainty } \\
/ \mathbf{~ m}^{\mathbf{2}}\end{array}$ & $\begin{array}{c}\text { Relative } \\
\text { uncertainty } \\
/ \mathbf{~ m}^{\mathbf{2}}\end{array}$ & $\boldsymbol{E}_{\mathbf{n}}$ \\
\hline $\begin{array}{l}\text { Manufacturer } \\
\text { Trim masses on the }\end{array}$ & $4.90267 \mathrm{E}-05$ & $\pm 3.9 \mathrm{E}-09$ & $\pm 80 \mathrm{E}-06$ & --- \\
$\begin{array}{l}\text { Standard Balance } \\
\text { Trim masses on the }\end{array}$ & $4.90317 \mathrm{E}-05$ & $\pm 2.1 \mathrm{E}-09$ & $\pm 42 \mathrm{E}-06$ & 1.1 \\
$\begin{array}{l}\text { Balance Under } \\
\text { Calibration }\end{array}$ & $4.90276 \mathrm{E}-05$ & $\pm 1.8 \mathrm{E}-09$ & $\pm 37 \mathrm{E}-06$ & 0.20 \\
& & & &
\end{tabular}

adjustment with trim masses is compatible using one or the other method for most of the target points calibrated.

As shown in Figures 1 and 2, comparing both results, the most significant difference for high accuracy pressure balances is in the low range of the calibration. On the other hand, the pressure generated by the trim masses, as shown in Tables 4 and 5 , is in the order of $1.7 \mathrm{kPa}$, which is less than $0.009 \%$ of the minimum range measured.

\section{CONCLUSIONS}

When comparing the $A_{0}$ results between the two methods with the Mexican national standard and alternatively with the results from the original calibration made by the manufacturer, both methods are compatible. Although, slightly better results were obtained by the method using the trim masses on the standard balance.

There is still more experiments to be carried out to discriminate other possible effects (i. e. different ranges, uncertainties, etc.). As general recommendation, it is better to use the minimum possible number of masses and trim masses.

\section{REFERENCES}

[1] Sabuga W., Bergoglio M., Rabault T., Waller B., Torres Guzman J. C., Olson D. A., Agarwal A., Kobata T., Bandyopadhyay A.K. PPTB, IMGC, BNM-LNE, NPL, CENAM, NIST, INMS/NRC, NMIJ/AIST, NPLI], Final Report on Key Comparison CCM.P$\mathrm{K} 7$ in the range $10 \mathrm{MPa}$ to $100 \mathrm{MPa}$ of Hydraulic gauge pressure. Metrologia 2005, 42, Tech. Suppl., 07005.

[2] Torres-Guzman J. C., Olvera-Arana P., Olson D., Hydraulic gauge pressure SIM comparison for a range up to $100 \mathrm{MPa}$. The 4th CCM International Conference on Pressure Metrology from Ultra-High Vacuum to very high pressure. England, 2005.

[3] Torres Guzmán J. C., Guía y Lineamientos Generales para Comparaciones de Patrones de Medición, Memorias del Segundo Congreso Internacional Metrocal. Concepción, Chile. April 2001. 